УДК 336.24

JEL Classification: A11, G22, L10

ЛІХОНОСОВА Г. С. ${ }^{1}$

\title{
ФОРМУВАННЯ ДИНАМІЧНОГО ПОТЕНЦАЛУ СТРАХОВОГО РИНКУ УКРАЇНИ
}

DOI: $10.32620 /$ cher.2020.1.07

Постановка проблеми. У статті наводяться авторська думка щодо особливостей функціонування страхового ринку України та специфічності формування його динамічного потенціалу. Актуальність проблематики обгрунтовується стрімкими змінами на ринку фінансових, а саме - страхових послуг у зв'язку з поширенням негативних очікувань виробничих структур, базуючись на світових прогнозах наступної глобальної фінансової кризи та світовим спадом обсягів виробництва. Метою cтатmi є експрес-характеристика сучасного стану ринку страхових послуг України та формування методичних положень щодо динамічного аналізу потенціалу страхового ринку із врахуванням впливу факторів зовнішнього середовища. Об'єктом дослідження виступає процес динамічного аналізу потенціалу страхового ринку із врахуванням впливу факторів зовнішнього середовища. Методи використані у дослідженні. Методологічною основою дослідження стали способи і принципи наукового пізнання, загальні та спеціальні методи, прийоми що використані при обгрунтуванні доцільності означення специфічності динамічного аналізу потенціалу страхового ринку із врахуванням впливу факторів зовнішнього середовища. Гіпотезою дослідження стало припущення, що довгострокова державна підтримка страхового ринку сприяє стимулюванню попиту при поступовому зростанні капіталізації. Виклад основного матеріалу. Підкреслено, що в умовах обмеження фінансових коштів в діяльності вітчизняних підприємств, слід спиратися на оновлення системи фінансового регулювання в країні, зокрема й за рахунок страхових інструментів, спрямовувати свою діяльність на залучення додаткових фінансових ресурсів. Наведено ескпрес-характеристику стану страхового ринку України, проведено динамічний та структурний аналіз показників страхового ринку та основних страхових послуг. Запропоновано рекомендації щодо проведення динамічного аналізу потенціалу ринку страхових послуг, які засновані на принципах аналізу сталого розвитку. Орихінальність та практична значимість дослідження. В дослідженні виявлено необхідність покращення ситуації на страховому ринку через реалізацію низки системних багатовекторних заходів, спрямованих на усунення як хронічних проблем, так і спричинених глобальної фінансовою кризою. Особливий акцент 3 точки зору практичної реалізації рекомендовано зробити на активізації інвестиційного потенціалу страхового ринку, формуванні ефективних ринкових механізмів залучення інвестиційних ресурсів у національну економіку за рахунок забезпечення ефективного функціонування ринку страхових послуг. Висновки та перспективи подальших досліджень. Проведене дослідження доводить те, що фактором, який забезпечує зростання страхового ринку з боку пропозиції, має стати підвищення капіталізації національних страховиків. У цих умовах особливої нагальності набудуть субординовані кредити та заходи щодо стимулювання рефінансування прибутку страхових компаній. Створення сприятливих умов для розвитку страхування потребує проведення глибоких теоретичних досліджень та надання наукових рекомендацій, які можуть стати важливим чинником ефективного функціонування національного страхового ринку.

Ключові слова:

страховий ринок, динамічний потенціал, аналіз ефективності страхових послуг, фінансова криза, сталий розвиток.

\section{FORMATION OF THE DYNAMIC POTENTIAL OF UKRAINE'S INSURANCE MARKET}

Formulation of the problem. The article presents the author's opinion on the peculiarities of the functioning of the Ukrainian insurance market and the specificity of its dynamic potential formation. The urgen-

${ }^{1}$ Ліхоносова Ганна Сергіївна, д-р екон. наук, професор кафедри «Фінанси», Національний аерокосмічний університет ім. М. Є. Жуковського «Харківський авіаційний інститут», м. Харків, Україна.

Likhonosova Ganna, Doctor of Economic Sciences, Professor of Finance Department National Aerospace University «Kharkiv Aviation Institute», Kharkiv, Ukraine.

ORCID ID: 0000-0001-6552-8920

e-mail: a.likhonosova@gmail.com 
cy of the problem is justified by the rapid changes in the financial market, namely, insurance services in connection with the spread of negative expectations of production structures, based on the global forecasts of the next global financial crisis and the global recession. The purpose of the article is to express the characteristics of the current state of the insurance market in Ukraine and the formation of methodological provisions for the dynamic analysis of the potential of the insurance market, taking into account the influence of environmental factors. The object of the study is the process of dynamic analysis of the potential of the insurance market, taking into account the influence of environmental factors. Methods used in the study. Methodological basis of the study were the methods and principles of scientific knowledge, general and specific methods used to justify the determination of the specificity of the dynamic analysis of the potential of the insurance market, taking into account the influence of environmental factors. The hypothesis of the study was the assumption that long-term government support for the insurance market helps stimulate demand with a gradual increase in capitalization. Presenting main material. It is emphasized that in the conditions of limitation of financial resources in the activity of domestic enterprises, it is necessary to rely on updating the system of financial regulation in the country, in particular at the expense of insurance instruments, to direct its activities to attract additional financial resources. Express characteristics of the insurance market of Ukraine are given, dynamic and structural analysis of insurance market indicators and main insurance services is carried out. Recommendations for dynamic analysis of the potential of the insurance market are offered, which are based on the principles of sustainable development analysis. Originality and practical significance of the study. The study identified the need to improve the situation in the insurance market through the implementation of a number of systematic multi-vector measures aimed at eliminating both chronic problems and caused by the global financial crisis. Particular emphasis in terms of practical implementation is recommended to activate the investment potential of the insurance market, the formation of effective market mechanisms for attracting investment resources in the national economy by ensuring the effective functioning of the insurance market. Conclusions and prospects for further research. The conducted research proves that the factor that ensures the growth of the insurance market from the supply side should be the increase of capitalization of national insurers. Under these conditions, subordinated loans and measures to stimulate the refinancing of profits of insurance companies will gain special urgency. Creating favorable conditions for the development of insurance requires deep theoretical research and scientific advice, which can be an important factor in the effective functioning of the national insurance market.

Key words:

insurance market, dynamic potential, analysis of insurance services efficiency, financial crisis, sustainable development.

\section{ФОРМИРОВАНИЕ ДИНАМИЧЕСКОГО ПОТЕНЦИАЛА СТРАХОВОГО РЫНКА УКРАИНЫ}

Постановка проблемы. В статье приводятся авторское мнение об особенностях функционирования страхового рынка Украины и специфичности формирования его динамического потенциала. Актуальность проблематики обосновывается стремительными изменениями на рынке финансовых, а именно - страховых услуг в связи с распространением негативных ожиданий производственных структур, основываясь на мировых прогнозах следующего глобального финансового кризиса и мировым спадом объемов производства. Целью статьи является экспресс-характеристика современного состояния рынка страховых услуг Украины и формирования методических положений относительно динамического анализа потенциала страхового рынка с учетом влияния факторов внешней среды. Объектом исследования выступает процесс динамического анализа потенциала страхового рынка с учетом влияния факторов внешней среды. Методы, использованные в исследовании. Методологической основой исследования стали способы и принципы научного познания, общие и специальные методы, приемы использованные при обосновании целесообразности определения специфичности динамического анализа потенциала страхового рынка с учетом влияния факторов внешней среды. Гипотезой исследования стало предположение, что долгосрочная государственная поддержка страхового рынка способствует стимулированию спроса при постепенном росте капитализации. Изложение основного материала. Подчеркнуто, что в условиях ограничения финансовых средств в деятельности отечественных предприятий, следует опираться на обновление системы финансового регулирования в стране, в том числе за счет страховых инструментов, направлять свою деятельность на привлечение дополнительных финансовых ресурсов. Приведены экспрессхарактеристику состояния страхового рынка Украины, проведено динамическое и структурный анализ показателей страхового рынка и основных страховых услуг. Предложены рекомендации по проведению динамического анализа потенциала рынка страховых услуг, основанных на принципах ана- 
лиза устойчивого развития. Оригинальность и практическая значимость исследования. В исследовании выявлена необходимость улучшения ситуации на страховом рынке через реализацию ряда системных многовекторных мер, направленных на устранение как хронических проблем, так и вызванных глобальным финансовым кризисом. Особый акцент с точки зрения практической реализации рекомендуется сделать на активизации инвестиционного потенциала страхового рынка, формировании эффективных рыночных механизмов привлечения инвестиционных ресурсов в национальную экономику за счет обеспечения эффективного функционирования рынка страховых услуг. Bbводы и перспективы дальнейших исследований. Проведенное исследование доказывает то, что фактором, обеспечивающим рост страхового рынка со стороны предложения, должно стать повышение капитализации национальных страховщиков. В этих условиях особую неотложность приобретут субординированные кредиты и меры по стимулированию рефинансирования прибыли страховых компаний. Создание благоприятных условий для развития страхования требует проведения глубоких теоретических исследований и предоставления научных рекомендаций, которые могут стать важным фактором эффективного функционирования национального страхового рынка.

\section{Ключевые слова:}

страховой рынок, динамический потенциал, анализ эффективности страховых услуг, финансовый кризис, устойчивое развитие.

Постановка проблеми. На сьогоднішній день головною умовою виживання бізнесу стає здатність підлаштовуватися під нові правила, продиктовані наслідками світової пандемії, а також, пов'язаного з нею - фінансової кризи. Страховий ринок України в цьому плані не виняток. Розвиток вітчизняного ринку страхових послуг в сучасних умовах тісно взаємопов'язано з розвитком національної економіки, оскільки дозволяе акумулювати значні довгострокові інвестиційні ресурси, залучаючи кошти через пенсійні програми i програми страхування життя. Розширення страхового бізнесу створює робочі місця, активізує впровадження інновацій, стимулює стійкість економіки і пом'якшує наслідки глобальних ризиків.

При більш детальному розгляді сутності страхової діяльності неважко помітити, що страхові компанії, одночасно виконують як традиційні для фінансових посередників функції (перераховані вище), так і специфічні, зокрема мінімізація економічних ризиків економічних суб'єктів і зниження ступеня невизначеності результатів їх господарської діяльності. Дискусійним питанням залишається належність потенціалу страхового ринку України до динамічних показників, тобто тих, які змінюються залежно від інших інтеграційних факторів зовнішнього середовища. Досліджуючи специфіку діяльності страхових компаній на фінансовому ринку, можна означити в ній ознаки, що дають підстави відносити страхові компанії як до фінансових посередників контрактно-заощаджувального типу, так і до цільових (інвестиційних) фондів. Тобто наочний характер динамічного ро- звитку та інтеграційного підгрунтя формування потенціалу страхового ринку.

Аналіз останніх досліджень та публікацій. Сутність потенціалу страхового ринку, інструменти його оцінювання і правовий аспект страхового бізнесу розглянуті в працях Акімової Л.М. [1, с. 475-481], Слободянюк O.B. [2, с. 126-131], Фурман B.M. [3, с. 61-64] та інших. 3'ясуванню сутності фінансового потенціалу страхового ринку присвячені праці Гаманкової О.О. [4], Шірінян Л. В. [5, с. 97-105], аналізу фінансового потенціалу страхової компанії - праці МарценюкРозарьонової О. В., Бондар А. В. [6, с. 61-65] та інших авторів. Нагально оцінюючи внесок вчених у розвиток інституту страхових відносин, слід відзначити, що ще недостатньо дослідженими залишаються питання щодо визначення сутності формування потенціалу страхового ринку та параметрів оцінювання його динамічних параметрів, їх інвестиційного потенціалу і його ролі у відтворювальній системі та впливу на соціально-економічний розвиток країни.

Метою статті $\epsilon$ експресхарактеристика сучасного стану ринку страхових послуг України та формування методичних положень щодо динамічного аналізу потенціалу страхового ринку із врахуванням впливу факторів зовнішнього середовища. Основою даного дослідження стали теоретичні положення системно-структурного підходу $[7$, с. 361,385$]$ та метод динамічного аналізу, що дозволило розглядати потенціал ринку страхових послуг як динамічний багатопараметричний об'єкт [8]. 
Виклад основного матеріалу дослідження. Події в сегменті страхування життя визначили гальмування загального зростання страхових премій. В останні роки страхування життя вважалося проривним напрямком бізнесу i радикально підвищувало загальні показники зборів страхового ринку. При цьому з 2011 р. по 2018 р. в Україні приріст премій страховиків життя забезпечував сегмент кредитного страхування життя позичальників. Тоді премії страховиків життя зростали темпами 53-60\% на рік. У 2017 і 2018 роках приріст зборів забезпечувала вже лінія продажів полісів страхування життя, річний приріст премій у страховиків життя досягав 36,5\%. За 9 місяців 2019 року збори зі страхування життя в Україні впали, отже, і загальноринковий показник страхових зборів впав [9]. У підсумку приріст премій за всіма видами страхування за 9 місяців 2019 року виявився на рівні $0,7 \%$. До кінця року зростання показника загальних річних зборів не перевищив $1 \%$.

Динамічний аналіз потенціалу ринку страхових послуг слід базувати на загально відомих принципах аналізу сталого розвитку $[10$, c. 38$]$ :

1) потенціал сталого розвитку є багатопараметричним об'єктом аналізу і управління, а діагностика та аналіз його стану потребує розробки системи показників, що забезпечить можливість комплексної всебічної оцінки;

2) декомпозиція вихідної множини багатопараметричного простору станів на класи чітких та нечітких множин різнорідних динамічних параметрів;

3) обгрунтування базисних значень показників (які визначають рівень найменших, але припустимих значень) та тих, що відповідають рівню бажаності (якого підприємство прагне досягти в найближчій перспективі) 3 метою визначення меж допусків параметрів;

4) орієнтація при визначенні бажаного рівня за кожним показником не на середній рівень, а на кращий світовий або вітчизняний досвід підприємств галузі;

5) єдність методичних підходів для забезпечення порівняння показників у динаміці та $з$ показниками інших підприємств;

6) візуалізація результатів оцінки потенціалу сталого розвитку як багатопараметричного об'єкту;

7) оцінка динамічної стійкості як окремих показників, так і потенціалу в цілому;
8) забезпечення аналізу як сприятливих, так і несприятливих факторів зовнішнього середовища 3 метою розробки комплексу адресних заходів 3 усунення їх негативного впливу на багатопараметричний об'єкт.

За останне десятиліття гірше виглядали тільки результати кризового 2009 року, коли збори знизилися на 6,6\%. В інші роки десятирічки приріст загальних премій коливався в діапазоні від 19,4\% до 3,3\%. У 2018 р. зростання премій страховиків досяг 15,7\% [9].

Частка добровільних видів страхування в преміях за 9 місяців виявилася на рівні $84,1 \%$, частка обов'язкових зборів - 15,9\%. При цьому активність в зборі премій зміщується в область особистого страхування - три квартали поспіль основний внесок в приріст премій забезпечує особисте страхування, тут збори зросли на $18 \%$ за 9 місяців. На частку особистого страхування в січні-вересні довелося 26,2\%, що на 3,9 процентного пункту (п.п.) більше, ніж за аналогічний період 2018 року. У тому числі премії з добровільного медичного страхування збільшилися на 15,8\% [9]. Прикметою року стала активність страхових компаній по виведенню на ринок продуктів добровільного медичного страхування для фізичних осіб - раніше компанії уникали цього через побоювання шахрайства, поліси добровільного медичного страхування продавалися в основному для співробітників клієнтів - юридичних осіб. Премії по страхуванню від нещасних випадків та хвороб за січеньвересень також помітно зросли - на 20,5\%, позначилося зростання обсягів кредитування позичальників.

Сектор добровільного страхування майна показав приріст зборів на 5,4\%, причому збори фізичних осіб збільшувалися швидше - на 8,9\% за підсумками 9 місяців 2019 року.

Виплати страхових компаній за 9 місяців в цілому за всіма видами страхування зросли на $17,5 \%$. При цьому в добровільному страхуванні обсяг виплат збільшився на $32,5 \%$, а в обов'язковому в 8 разів скромніше - на 3,9\%. Виплати по страхуванню життя за той же період підскочили на 98,2\%. За всіма особистих видів страхування приріст виплат склав $11,7 \%$ за 9 місяців. Разом з тим виплати по страхуванню майна юридичних осіб впали на $29 \%$.

На тлі тенденцій падіння премій і зростання виплат показник чистого прибутку страховиків за січень-вересень збільшився на 
$10,2 \%$, однак темпи приросту показника скоротилися приблизно в 9 разів за рік. Незважаючи на збільшення збитковості, рентабельність капіталу страхових компаній зросла до 30,9\% за 9 місяців року. Цьому сприяло, як зазначається в огляді ключових показників Національного банку України, "збільшення доходів від інвестиційної діяльності, пов'язане 3 ростом облігаційного ринку, на тлі нарощування часткою вкладень в корпоративні та державні боргові інструменти в активах страховиків" [11]. В НБУ прогнозують рівень цього показника за підсумками цього року близько $22 \%$, в те брешемо як в банківському секторі він очікується на рівні 5,6-5,8\%.

Комбінований коефіцієнт збитковості в цілому по ринку за 9 місяців склався на рівні 95,4\%. Винагороди продають посередникам в січні-вересні зросли порівняно 3 аналогічним періодом минулого року на $26,9 \%$. Доміную- чими партнерами в продажах полісів залишаються банки.

Концентрація страхового сектора продовжувала збільшуватися за перші три квартали року: на частку десятки найбільших страховиків довелося $68,7 \%$ обсягів ринку по зборах, тоді як роком раніше цей показник становив $64,5 \%$.

Для страховиків обов'язкового страхування цивільної відповідальності власників транспортних засобів 2019 рік був роком очікувань. Вони виправдалися не повною мірою. Реформа індивідуалізації тарифів в "автоцивілці" почалася в січні, але вийти на другий етап реформи 31 січня 2020 року був не судилося - не готові законодавчі зміни [9].

На 31 березня 2019 року страховиківліцензіатів налічувалося 250. У найбільш масових видах страхування частка ТОП-20 становить понад $80 \%$.

Т а б ли ц я 1

Концентрація страхового ринку України, 2019 р.

\begin{tabular}{|r|l|c|c|c|c|}
\hline № & \multicolumn{1}{|c|}{ Вид страхування } & ТОП-3 & ТОП-5 & ТОП-10 & ТОП-20 \\
\hline 1 & Страхування життя & 54,6 & 78,7 & 96,7 & 100,0 \\
\hline 2 & Страхування від нещасних випадків & 58,4 & 69,9 & 81,1 & 88,8 \\
\hline 3 & КАСКО & 37,2 & 50,5 & 69,2 & 84,0 \\
\hline 4 & Добровільне медичне страхування & 31,2 & 44,1 & 63,8 & 80,5 \\
\hline 5 & $\begin{array}{l}\text { Обов'язкове страхування цивільної } \\
\text { відповідальності власників транс- } \\
\text { портних засобів }\end{array}$ & 26,9 & 36,3 & 56,2 & 77,5 \\
\hline 6 & Страхування майна & 23,7 & 36,3 & 57,6 & 80,8 \\
\hline 7 & Страхування вантажів & 32,7 & 47,7 & 68,4 & 85,7 \\
\hline 8 & Страхування туристів & 31,9 & 43,7 & 63,5 & 83,2 \\
\hline 9 & Агрострахування & 69,3 & 80,2 & 95,8 & 99,6 \\
\hline 10 & $\begin{array}{l}\text { Страхування цивільної відповідаль- } \\
\text { ності }\end{array}$ & 19,9 & 31,5 & 55,6 & 80,9 \\
\hline
\end{tabular}

Джерело: розроблено автором на підставі [13; 14]

У той же час, незважаючи на скорочення кількості страховиків, капіталізація діючих компаній зросла. Так, їх активи станом на 31 грудня 2019 року в порівнянні з минулорічним періодом зросли на 6,1 млрд грн, або на $10,6 \%$, а страхові резерви - на 3,8 млрд грн або на 16,6\%. При ці активи, що приймаються доводиться 68,5\% [15].

У структурі розміщення прийнятих активів на 31.12.2019 поточні рахунки і депозити страховиків в банках склали 34\% або 15,2 млрд грн., Державні папери - 19\% або 7,9 млрд грн, права вимоги до перестрахувальників-нерезидентів - 8,3\% або 3,4 млрд грн і нерухомість - 7\% або 2,9 млрд. грн.
Низький обсяг якісних пропозицій фондового ринку призвели до того, що інвестиції страховиків в акції та корпоративні облігації склали 722 млн грн або всього 1,7\% прийнятих активів. Це пов'язано, перш за все, 3 новими вимогами до розміщення страхових резервів, які передбачені Положенням про обов'язкові критерії та нормативи достатності капіталу та платоспроможності, ліквідності, прибутковості, якості активів та ризиковості операцій страховика, затвердженого розпорядженням Національної комісії фінансових послуг №850 від 07.06.2018 [13].

Зміна регуляторної бази сприяло не тільки посилення платоспроможності страхо- 
вих компаній, але і поліпшення результативності їх інвестиційної політики. Так за 2019 рік страховики отримали інвестиційний дохід в розмірі 2,4 млрд грн, в т.ч. близько 1,4 - це відсотки за депозитами і понад 720 млн грн дохід по облігаціях. Щодо 2018 року прибут- ковість інвестицій страховиків в 2019 році збільшилася на 20,2\% або на 405 млн грн, при цьому прибутковість облігації зросла на $23,6 \%$ або на 138 млн грн, а депозитів - на 19,7\% або 235 млн грн (таблиця 2).

Структура розміщення активів страховиків, 2019 p.

\begin{tabular}{|r|l|c|c|c|}
\hline \multicolumn{1}{|c|}{ № } & \multicolumn{1}{|c|}{ Показник } & $\begin{array}{c}\text { На 30.09.2019, } \\
\text { млн. грн. }\end{array}$ & $\begin{array}{c}\text { На 31.12.2019, } \\
\text { млн. грн. }\end{array}$ & 3міни, \% \\
\hline 1 & Грошові кошти на поточних рахунках & 2991,0 & 2853,4 & $-4,6 \%$ \\
\hline 2 & Банківські вклади (депозити) & 12463,3 & 12338,8 & $-1,0 \%$ \\
\hline 3 & Банківські метали & 8,1 & 30,5 & $276,5 \%$ \\
\hline 4 & Нерухоме майно & 2607,6 & 2922,5 & $12,1 \%$ \\
\hline 5 & Акції & 111,4 & 114,6 & $2,9 \%$ \\
\hline 6 & Облігації & 514,8 & 637,6 & $23,9 \%$ \\
\hline 7 & Цінні папери, що емітуються державою & 7404,6 & 7885,6 & $6,5 \%$ \\
\hline 8 & Права вимоги до перестраховиків & 4620,9 & 5248,6 & $13,6 \%$ \\
\hline 9 & Інвестиції в економіку України & 93,3 & 1187,4 & $1172,7 \%$ \\
\hline 10 & Кредити страхувальникам-громадянам & 16,2 & 17,5 & $8,0 \%$ \\
\hline 11 & $\begin{array}{l}\text { Довгострокові кредити для житлового } \\
\text { будівництва }\end{array}$ & 0,2 & 0,2 & $0,0 \%$ \\
\hline 12 & Готівка в касі & 10,1 & 12,9 & $27,7 \%$ \\
\hline 13 & Транспортне страхове бюро України & 2122,3 & 2360,9 & $11,2 \%$ \\
\hline 14 & $\begin{array}{l}\text { Непрострочена дебіторська заборгова- } \\
\text { ність }\end{array}$ & 4676,0 & 7857,4 & $68,0 \%$ \\
\hline 15 & $\begin{array}{l}\text { Відстрочені аквізиційні витрати (які не } \\
\text { є прийнятним активом) }\end{array}$ & 1319,6 & 1602,0 & $21,4 \%$ \\
\hline 16 & Разом прийнятних активів & 37642,3 & 43466,1 & $15,5 \%$ \\
\hline 17 & $\begin{array}{l}\text { Частка прийнятних активів в загальних } \\
\text { активах,\% }\end{array}$ & 63,3 & 68,5 & $8,2 \%$ \\
\hline
\end{tabular}

Джерело: розроблено автором на підставі [13; 14]

Основні регуляторні зміни, які відбулися в структурі і змісті страхового ринку України [15]:

-введено електронний поліс обов'язкового страхування цивільно-правової відповідальності власників наземних транспортних засобів (укладено понад 140 тис договорів);

-вдосконалено звітність страховиків i переведена іï подача в Національній комісії фінансових послуг виключно в електронній формі, що сприятиме скороченню часу обробки звітності та підвищувати ефективність пруденційного нагляду;

-введено звіт актуарія, а також істотно оновлена Методика формування страхових резервів за видами страхування іншими, ніж страхування життя, що сприятиме адекватному приведення страхових резервів у відповідність 3 прийнятими зобов'язаннями;
- створені правові передумови використання іноземної валюти на ринку страхування життя;

- посилений нагляд на консолідованій основі за небанківськими фінансовими групами;

-введено фінансове забезпечення обов'язкового аудиту (затверджений типовий договір добровільного страхування цивільноправової відповідальності суб'єкта аудиторської діяльності перед третіми особами, тобто створений перший прецедент відмови від обов'язкового страхування шляхом запровадження страхування у формі обов'язкового умови для здійснення певного виду підприємницької діяльності, зокрема проведення обов'язкового аудиту);

-введені вимоги до методики розрахунку викупної суми за договором страхування 
життя, що сприятиме забезпеченню прав та інтересів споживачів [16].

На сьогодні страховики забезпечують не тільки доступність страхових послуг для різноманітних клієнтських категорій і розширюють експансію в регіонах країни (відкрито 33 філії), але створюють нові робочі місця 3 податковими відрахуваннями, в т.ч. до місцевих бюджетів. Зокрема, страховики за 2019 рік сплатили податку на прибуток в розмірі близько 1,2 млрд грн, що на 11,3\% або на 119 млн грн. більше ніж у 2018 році [15].

У 2019 року страхові компанії продемонстрували активне зростання надання послуг населенню, а також підприємствам малого і середнього бізнесу. Зокрема, надходження страхових платежів від населення склали 3 ризикового страхування близько 14,6 млрд грн, що на 14,9\% або 1,9 млрд грн. більше ніж за 2018 рік. Страхові виплати населенню і підприємствам за 2019 рік склали 12,9 млрд грн., Що 22,1\% або на 2,3 млрд грн. більше показника за попередній рік.

В результаті регуляторного впливу та під впливом кон'юнктури ринку страхові компанії розмістили $35 \%$ на депозитах в державних банках, 38\% - в банках з іноземним капіталом, а ризики своїх клієнтів в самих надійних перестрахувальників переважно 3 таких країн як Німеччина, Швейцарія, Австрія, Великобританія, Польща, США [12].

У 2020 р. Національна комісія фінансових послуг прогнозує зосередження уваги на вирішенні завдань, спрямованих на вдосконалення державного регулювання в частині проведення фінансового моніторингу, врегулювання операцій перестрахування, посилення заходів впливу до проблемних і неплатоспроможним страховикам, врегулювання при передачі страхового портфеля, проведення стрес-тестування страховиків, встановлення вимог до аудиторських звітів.

Висновки та перспективи подальших досліджень. Виходячи 3 вищенаведеного, держава має наразі вжити ряд заходів, спрямованих на розвиток попиту на страхування. На перспективу в 5-7 років доцільно передати роль основних драйверів розвитку ринку поставлений і обов'язкових видів страхування. Страхування повинно стати одним 3 найважливіших елементів промислової і торговельної політики держави, в тому числі в сфері підтримки малого бізнесу, субсидування окремих галузей економіки, захисту власних фінансових інтересів держави. Фактором, що забезпечує зростання страхового ринку з боку пропозиції, повинно стати підвищення капіталізації національних страховиків. У цих умовах особливої нагальності набудуть субординовані кредити та заходи щодо стимулювання рефінансування прибутку страхових компаній.

Після відновлення докризового обсягу попиту на страхування потреба української страхової галузі в капіталі буде стрімко рости. При цьому якщо ніяких заходів вжито не буде, недостатньою рівень капіталізації страхової галузі стане основним фактором, що стримує розвиток страхового ринку, і призведе до зростання частки внесків, переданих у перестрахування за кордон.

\section{Література}

1. Акімова Л.М. Сучасний стан та проблеми розвитку страхового ринку в Україні. Ефективність державного управління. 2014. Вип. 40. С. 475-481.

2. Фурман В.М. Особливості та сутність страхового ринку. Фінанси Украйни. 2005. № 4. C. 126-131.

3. Слободянюк О.В. Страховий ринок у категоріях інституціональних теорій. Економіка та держава. 2016. №2. С. 61-64.

4. Гаманкова О.О. Ринок страхових послуг Украйни: теорія, методологія, практика: монографія. Київ: КНЕУ, 2009. 283 с.

5. Шірінян Л.В. Вплив розмірів страхових компаній на ефективність діяльності і розподіл на ринку страхових послуг в Україні. Економіка і прогнозування. 2011 №4. С.97-105

6. Марценюк-Розарьонова О. В., Бондар А. В. Аналіз фінансового потенціалу страхової компанії та механізму його формування. Інвестииїі: практика та досвід. 2018. № 22. C. 61-65.

7. Економічна енциклопедія: У трьох томах. Т.3. / Відп. С.В. Мочерний ред. Київ: Видавничий центр "Академія", 2002. 952 с.

8. Колобов А.А. Омельченко И.Н., Орлов А.И. Менеджмент высоких технологий. Интегрированные производственнокорпоративные структуры: организация, экономика, управление, проектирование, эфррективность, устойчивость. Москва: Издательство "Экзамен", 2008. 621 с.

9. Залетов А. Отчет международного перестраховщика Swiss Re. URL: https://interfax.com.ua/ (Дата звернення: 12.01 .2020 p.) 
10. Тарасенко I. О. Динамічний аналіз потенціалу підприємства в системі управління сталим розвитком. Інвестиції: практика та досвід. 2009. № 21. С. 36-40.

11. Про затвердження Програми розвитку страхового ринку України на 2001 - 2004 роки: Постанова Кабінету Міністрів України від 02.02.2001 p. № 98. URL: htpp://zakon.rada.gov.ua (Дата звернення: 13.01.2020 p.)

12. Competition and related regulation issues in the insurance industry. URL: htpp://www.oecd.org/daf/clp (Дата звернення: 15.01.2020 p.)

13. Статистика страхового ринку України. URL: htpp://www.forinsurer.com (Дата звернення: 12.02 .2020 p.)

14. Богута Н. Рейтинг страховых компаний $\quad-\quad 2019.2$ URL: http://dengi.ua/archive/articles/311020-Rejtingstrahovyh-kompanij-2019 (Дата звернення: 02.01.2020 p.)

15. Офіційний сайт Національної комісії, що здійснює державне регулювання у сфері ринків фінансових послуг. URL: htpp://www.nfp.gov.ua//content/rzvitinackomfinposlug (Дата звернення: 17.01.2020 р.)

16. Kendall M.G. Rank Correlation Methods. N.Y.: Heffner Publ.Go.,1995. 196 p.

\section{References}

1. Akimova, L.M. (2014). The current state and problems of development of the insurance market in Ukraine. Public administration efficiency, 40, 475-481.

2. Furman, V.M. (2005). Features and essence of the insurance market. Finance of Ukraine, $4,126-131$.

3. Slobodyanyuk, O.V. (2016). Insurance market in the categories of institutional theories. Economy and the state, 2, 61-64.

4. Gamankova, O.O. (2009). Insurance market of Ukraine: theory, methodology, practice: monograph. Kyiv: KNEU, 283.

5. Shirinyan, L.V. (2011). Influence of size of insurance companies on efficiency of activity

Стаття надійшла

до редакції : 01.02.2020 p. and distribution in the market of insurance services in Ukraine. Economics and forecasting, 4, 97-105.

6. Martseniuk-Rosaryonova, O.V. \& Bondar, A.V. (2018). Analysis of the financial potential of an insurance company and the mechanism of its formation. Investment: practice and experience, 22, $61-65$.

7. Mocherniy, S.V. (2002). The Economic Encyclopedia: In three volumes. Vol. 3. Kyiv: Academia Publishing Center, 952.

8. Kolobov, A.A. Omelchenko, I.N., Orlov, A.I. (2008). High technology management. Integrated production and corporate structures: organization, economy, management, design, efficiency, sustainability. Moscow: "Exam" Publishing House, 621.

9. Zaletov, A. (2020). Report of the International Reinsurer Swiss Re. Retrieved from: https://interfax.com.ua/ (Accessed: 01/12/2020)

10. Tarasenko, I.O. (2009). Dynamic analysis of enterprise potential in the system of sustainable development management. Investment: practice and experience, 21, 36-40.

11. On approval of the Program of development of the insurance market of Ukraine for 2001 2004: Resolution of the Cabinet of Ministers of Ukraine dated 02.02.2001 No. 98. Retrieved from: htpp: //zakon.rada.gov.ua (Accessed: 01/13/2020)

12. Competition and related regulation issues in the insurance industry. Retrieved from: htpp: //www.oecd.org/daf/clp (Accessed: 01/15/2020)

13. Statistics of the Ukrainian insurance market. Retrieved from: htpp: //www.forinsurer.com (Accessed: 02/12/2020)

14. Boguta, N. Rating of insurance companies - 2019. Retrieved from: http://dengi.ua/archive/articles/311020-Ratingstrahovyh-kompanij-2019 (Accessed: 02/01/2020)

15. Official site of the National Commission for the State Regulation of Financial Services Markets. Retrieved from: htpp: //www.nfp.gov.ua//content/rzviti-nackomfinposlug (Accessed: 01/17/2020)

16. Kendall, M.G. (1995). Rank Correlation Methods. N.Y.: Heffner Publ.Go., 196.

\section{Стаття прийнята \\ до друку: 03.03.2020p.}

Бібліографічний опис для цитування :

Ліхоносова Г. С. Формування динамічного потенціалу страхового ринку України / Г. С. Ліхоносова // Часопис економічних реформ. - 2020. - № 1 (37). - С. 49-56. 